\title{
Sensory, Physicochemical and Antioxidants Evaluation of Kecombrang (Etlingera elatior) Preservative Powder with Foam- mat Drying Method for Beef Meatballs Products
}

\author{
Rifda Naufalin*, Erminawati Wuryatmo, Rumpoko Wicaksono and Laila Sausan El Islami \\ Department of Food Technology, Faculty of Agriculture, Jenderal Soedirman University \\ Jl. Dr. Soeparno 61 Purwokerto 53123 Central Java Indonesia \\ *Corresponding author email: rifda.naufalin@unsoed.id
}

\begin{abstract}
This study aims to determine the effect of the type and concentration of preservative powder with foam-mat drying method to produce optimal beef meatballs products seen from the chemical, sensory, and antioxidant evaluation. This study used an experimental method with a randomized block design with the factors being studied were the type of powder of kecombrang plant parts, namely flowers and stems with the concentrations used, namely $0 \%, 1 \%, 2 \%$, and $3 \%$. Physicochemical analysis was performed on moisture content, $\mathrm{pH}$, and total protein hydrolyzed (Formol test). The sensory evaluation was carried out by 25 trained people using the descriptive and hedonic testing methods on a scale of 1-5 (very dislike to very much like). Meanwhile, the best treatment from the results of physicochemical and sensory evaluation was analyzed of bioactive compounds (antioxidants) was carried out on total flavonoids and total phenols. The results showed that the best treatment combination was the type of flower preservative with a concentration of $2 \%$ which had characteristics with an average moisture content of $57.19 \pm 5.71 \%$, pH $7.1 \pm 0.21$, hydrolyzed protein content (Formol) $1.40 \pm 0.35 \%$, whitish-gray color ( $2.72 \pm 1.40)$, scents of meat and kecombrang (3.64 \pm 0.49 ), slightly chewy texture (3.52 \pm 0.65$)$, flavored with meat and kecombrang $(3.68 \pm 0.75)$, is rather preferenced by panelists ( $3.12 \pm 0.97$ ), and results of antioxidants evaluation were total flavonoids $2.42 \mathrm{mg} \mathrm{QE} \mathrm{/} 100 \mathrm{mg}$, total phenolic $179.53 \mathrm{mg}$ QE / $100 \mathrm{mg}$. The concentration of kecombrang flower and stems powder suitable for adding to beef meatballss is seen from the physicochemical and sensory evaluation up to $2 \%$.
\end{abstract}

Keywords: kecombrang, meatball, natural preservative, foam-mat drying method, sensory

Abstrak. Penelitian ini bertujuan untuk mengetahui pengaruh jenis dan konsentrasi serbuk pengawet dengan metode foam-mat drying untuk menghasilkan produk bakso sapi yang optimal dilihat dari evaluasi kimiawi, sensoris, dan antioksidan. Penelitian ini menggunakan metode eksperimen dengan Rancangan Acak Kelompok dengan faktor yang diteliti adalah jenis serbuk bagian tanaman kecombrang yaitu bunga dan batang dengan konsentrasi yang digunakan yaitu $0 \%, 1 \%, 2 \%$, dan $3 \%$. Analisis fisikokimia dilakukan terhadap kadar air, $\mathrm{pH}$, dan protein total terhidrolisis (uji Formol). Evaluasi sensori dilakukan oleh 25 orang terlatih menggunakan metode pengujian deskriptif dan hedonik pada skala 1-5 (sangat tidak suka hingga sangat suka). Sedangkan perlakuan terbaik dari hasil evaluasi fisikokimia dan sensorik dilakukan analisis senyawa bioaktif (antioksidan) berupa total flavonoid dan total fenol. Hasil penelitian menunjukkan bahwa kombinasi perlakuan terbaik adalah jenis pengawet bunga dengan konsentrasi $2 \%$ yang mempunyai karakteristik dengan kadar air rata-rata $57,19 \pm 5,71 \%$, pH 7,1 $\pm 0,21$, kadar protein terhidrolisis (Formol) 1,40 $\pm 0,35 \%$, warna abu-abu keputihan $(2,72$ $\pm 1,40)$, aroma daging dan kecombrang $(3,64 \pm 0,49)$, tekstur agak kenyal $(3,52 \pm 0,65)$, dibumbui dengan daging dan kecombrang $(3,68 \pm 0,75)$, disukai oleh panelis $(3,12 \pm 0,97))$, dan hasil evaluasi antioksidan didapatkan total flavonoid 2,42 mg QE / $100 \mathrm{mg}$, total fenolik 179,53 mg QE / $100 \mathrm{mg}$. Konsentrasi tepung bunga dan batang kecombrang yang sesuai untuk ditambahkan pada bakso sapi dilihat dari evaluasi fisikokimia dan sensoris sebesar $2 \%$.

Kata kunci: kecombrang, bakso, pengawet alami, metode foam-mat drying, sensori

\section{Introduction}

The increased awareness of society to the importance of maintaining health goes in line with the consumer demand for foodstuffs. Consumers nowadays place importance not only on economic factors but also on the health and nutritional value of the foodstuff they consume. In developed countries, consumers are concerned about the nutritional content and delicious taste of food as well as its effect on body health. The available foodstuffs which 
contain harmful ingredients have made the consumers more selective about the foodstuffs they consume.

Meatballs is a processed meat product made from minced meat mixed with seasoning and flour, then made into small balls and boiled in hot water (Montolalu et al., 2017). Meatballs can be made from beef, chicken, fish, pork, and other meats. Meatballs in the market are mostly beef. The shelf life of meatballs is usually short, from 12 hours to a maximum of 1 day in room temperature (Widyaningsih and Murtini, 2006) or 4-5 days in cool storage of $5^{\circ} \mathrm{C}$ (Alishahi and Aïder, 2012).

The short shelf life has inspired meatballs producers to use preservatives, such as acetic acid, benzoate acid, or nitrate and nitrite. However, the use of preservatives is restricted to a particular limit, and excessive dosage would impose detrimental effects on consumers' health (Latifasari et al., 2019). Therefore, it is necessary to extend the shelf life of meatballs using natural preservatives that exhibit antimicrobial and antioxidants properties.

A natural preservative for meatballs that can extend the shelf life without affecting the taste is kecombrang flower. Previous research (Naufalin, 2019) reported that kecombrang flower (Etlingera elatior) is a part of kecombrang plants with antimicrobial and antioxidants effects. Kecombrang plants contain bioactive compounds, such as alkaloid, saponin, phenolic, flavonoids, triterpenoid, steroid, and glycoside that are active antimicrobial or antioxidants agents. The other parts of the plant that can be harnessed to extend the shelf life of meatballs are kecombrang stem. (Naufalin and Rukmini, 2012) reported that incorporating $1 \%$ kecombrang powder stem into mackerel fish meatballs could decrease the total bacteria by $1.31 \mathrm{CFU} / \mathrm{g}$ and total mold and yeast by $1.18 \mathrm{CFU} / \mathrm{g}$.
Accordingly, the higher concentrate of kecombrang powder stem would extend the shelf life of mackerel fish meatballs.

Kecombrang is a natural preservative for food that can be made into powder using the foam-mat drying method. This method can accelerate water evaporation process and performs at a low temperature, so it prevents the cell tissue from damage and preserves the nutritional values (Rajkumar et al., 2007). Kecombrang powder is easy to save and use. Preservatives must be used in a proper concentration to render an optimum effect on inhibiting microbes as well as exhibiting sensory qualities that the public can accept.

Accordingly, this research aimed to evaluate the effect of foam-mat-dried kecombrang flower and stem powder on the physiochemical, antioxidants, and sensory properties of beef meatballs.

\section{Materials and Method}

\section{Materials and Research Design}

The primary materials for this study were kecombrang kecombrang preservative powder and minced beef. The study was experimental in a Randomized Block Design (RBD) with factors including two types of preservatives, i.e., kecombrang flower and kecombrang stem, and the level of preservatives for beef meatballs, i.e., $1 \%, 2 \%$, and $3 \%$. A total of six treatments and four replicates made up 24 treatment units.

\section{Producing kecombrang flower and stem powder}

Fresh kecombrang flower and stem were sorted and chopped to bits and dried in a cabinet dryer at $50-60{ }^{\circ} \mathrm{C}$ for 4 hours. Kecombrang dried simplisia was pulverized using a disc mill and sifted using a 60-mesh sieve to obtain kecombrang flower and stem powder (Naufalin et al., 2019). 


\section{Producing liquid extract of kecombrang flower and stem}

Kecombrang powder (flower and stem) and water with a ratio of $1: 14(\mathrm{~b} / \mathrm{v})$ were incorporated in an extractor. The extraction process of kecombrang flower and stem was performed at $60{ }^{\circ} \mathrm{C}$ for 4 hours (Naufalin and Rukmini, 2018).

\section{Producing kecombrang preservative powder with foam-mat drying method}

Fifty $\mathrm{ml}$ of liquid extract was mixed with $10 \%$ maltodextrin and $1 \%$ Tween 80 using a mixer for 15 minutes until frothing, then poured on baking sheets and dried in a cabinet dryer for 4 hours at $50^{\circ} \mathrm{C}$.

\section{Moisture content analysis}

One gram of sample was weighed in a moisture analyzer cup and heated up to $120^{\circ} \mathrm{C}$. After that, the moisture analyzer was closed and let sit to read the result of moisture content. The result was recorded (AOAC, 1995).

\section{pH analysis}

A pH meter was calibrated with buffer $\mathrm{pH} 4$ and $\mathrm{pH} 7$ before measuring the sample $\mathrm{pH}$. Ten grams of sample was mixed with $50 \mathrm{ml}$ Aquadest and homogenized. The $\mathrm{pH}$ was measured by placing electrodes on the sample, and the $\mathrm{pH}$ is read on the $\mathrm{pH}$ meter (Sudarmadji, 1997).

\section{Analysis of hydrolyzed protein level (Formol} Test)

Two grams of chicken sausage sample mashed with a porcelain cup was dissolve in $20 \mathrm{ml}$ of Aquadest, mixed with a stirrer for 15 minutes, and filtered to take $10 \mathrm{ml}$ of the filtrate. The filtrate was put into a $125 \mathrm{ml}$ Erlenmeyer, incorporated with $20 \mathrm{ml}$ Aquadest, $0.4 \mathrm{ml}$ calcium oxalate saturation ( $\mathrm{K}$-oxalate: water $=1: 3)$, and $1 \mathrm{ml}$ of PP indicator, and let sit for 2 minutes. The sample solvent was titrated with $\mathrm{NaOH} 0.1 \mathrm{~N}$ until it turned pink. The titrated sample was added with $2 \mathrm{ml}$ of $40 \%$ formaldehyde and re-titrated with $\mathrm{NaOH} 0.1 \mathrm{~N}$ until it turned pink (titration II), then the $\mathrm{NaOH}$ volume was recorded and the protein level was calculated (Sudarmadji, 1997).

\section{Sensory evaluation}

The sensory evaluation of the beef meatball sample was performed using a descriptive and hedonic test. The descriptive test was performed by 25 trained panelists. The first step was preparing the test samples bearing a random three-digit number code, the second step was serving the sample on a styrofoam plate/tray simultaneously, and the last code was asking the panelists to fill out the evaluation form based on the scale. The hedonic test was performed to indicate the

Table 1. Description sensory of hedonic test

\begin{tabular}{|c|c|c|c|c|c|}
\hline Skor & Color & Scent & Texture & Flavor & Preference \\
\hline 1 & Gray blackish & $\begin{array}{l}\text { Very scented } \\
\text { kecombrang }\end{array}$ & $\begin{array}{l}\text { Very not } \\
\text { chewy }\end{array}$ & $\begin{array}{l}\text { Very strong } \\
\text { Kecombrang taste }\end{array}$ & Dislike \\
\hline 2 & Gray whitish & $\begin{array}{l}\text { Scented } \\
\text { kecombrang }\end{array}$ & Not chewy & Kecombrang taste & Rather like \\
\hline 3 & $\begin{array}{l}\text { Gray } \\
\text { brownish }\end{array}$ & $\begin{array}{l}\text { Scented meat } \\
\text { and }\end{array}$ & $\begin{array}{l}\text { Rather } \\
\text { chewy }\end{array}$ & $\begin{array}{l}\text { Kecombrang and } \\
\text { meaty blended taste }\end{array}$ & Rather like \\
\hline 4 & & kecombrang & & Meaty taste & Like \\
\hline 5 & $\begin{array}{l}\text { Gray } \\
\text { Gray redness }\end{array}$ & $\begin{array}{l}\text { Scented meat } \\
\text { Very scented } \\
\text { meat }\end{array}$ & $\begin{array}{l}\text { Chewy } \\
\text { Very chewy }\end{array}$ & Very meaty taste & $\begin{array}{l}\text { Like very } \\
\text { much }\end{array}$ \\
\hline
\end{tabular}


level of food preference in general as instructed by the food server.The panelists gave their evaluation based on the 1-5 point hedonic scale. Description sensory of hedonic test can seen in Table 1 . To verify the preference on beef meatballs as well as standardize and evaluate each sensory attribute, the total acceptable factor (AF) was determined based on the formula below (Dutcosky, 1996):

$A F=A \times 100 \times B^{-1}$

Note: $\mathrm{A}=$ mean of each attribute; $\mathrm{B}=$ maximum mean of each attribute.

The determination of the selected preservatives was based on the highest average value of all attributes. Afterwards, flavanoids and total phenolic analysis were tested on the selected preservatives.

\section{Flavonoids Analysis}

Twenty-five milligrams of quercetin were dissolved in $96 \%$ ethanol pro analysis up to $25 \mathrm{ml}$ as the mother liquor (1000 ppm). One $\mathrm{ml}$ of the mother liquor was dissolved in $10 \mathrm{ml}$ of $69 \%$ ethanol pro analysis (100 ppm). The solvent was diluted in a series of $6 \mathrm{ppm}, 8 \mathrm{ppm}$, $10 \mathrm{ppm}, 12 \mathrm{ppm}$ and $14 \mathrm{ppm}$ to create a standard curve. Then, $1 \mathrm{~g}$ sample was incorporated with $10 \mathrm{ml}$ of $96 \%$ ethanol in a shaker and shaken at a speed of $200 \mathrm{rpm}$ for 2 hours. The supernatant yield was the extract to determine the sample. As much as $\mathrm{k} 100 \mu \mathrm{L}$ or $0.1 \mathrm{ml}$ supernatant sampel was mixed with $1 \mathrm{ml}$ $\mathrm{AlCl}_{3} 2 \%\left(2 \mathrm{~g} \mathrm{AlCl}_{3}\right.$ in $100 \mathrm{ml}$ of glacial acetic acid $5 \%$ ) and $1 \mathrm{ml}$ of $120 \mathrm{Mm}$ kalium acetate (1.176 $\mathrm{g}$ kalium acetate in $100 \mathrm{ml}$ of Aquadest). The sample was incubated for one hour at room temperature and measured for the absorbability using a spectrophotometer at 435 nm wavelength (Sudarmadji, 1997).

\section{Total phenolic analysis}

Tannic acid was used as the standard. As much as $10 \mathrm{mg}$ tannic acid was diluted in $100 \mathrm{ml}$ of $95 \%$ ethanol as the stock solvent solution and subjected to a series of dilution for 0.02 $\mathrm{mg} / \mathrm{ml}, 0.04 \mathrm{mg} / \mathrm{ml}, 0.06 \mathrm{mg} / \mathrm{ml}, 0.08 \mathrm{mg} / \mathrm{ml}$, and $0.1 \mathrm{mg} / \mathrm{ml}$ to create a standard curve. After that, a $0.01 \mathrm{~g}$ sample was mixed with $10 \mathrm{ml}$ of $70 \%$ ethanol, shaken with a vortex to prepare for the sample. The supernatant yield was the extract to determine the sample. A quantity of $0.4 \mathrm{ml}$ sample was added with $1.5 \mathrm{ml}$ of $10 \%$ Folin-Ciocalteu and let sit for five minutes at room temperature. Then, $1.5 \mathrm{ml}$ sodium bicarbonate ( $\mathrm{NaHCO}$ ) $0.556 \mathrm{M}$ was shaken, let sit in a dark room for 90 minutes and measured for the absorbability at $725 \mathrm{~nm}$ wavelength (Singleton and Rossi, 1965).

\section{Data analysis}

The data of chemical test were subjected to Analysis of Variance (ANOVA) at 5\% level of significance and any significant difference was analysed further using Duncan's Multiple Range Test (DMRT). Data of variable sensory were analysed with Friedman Test, and Effectivity Index was used to determine the best treatment combination.

\section{Result and Discussion}

\section{Moisture content}

The moisture content of the treatment combination for beef meatballs with kecombrang powder was $51.76 \pm 6.65$ to $64.82 \pm 1.65 \%$. The moisture content of beef meatballs decreased with an increased level of kecombrang powder (Figure 1). It is presumably because kecombrang powder can absorb water, so it is a hydrophilic compound (Naufalin, 2020).

\section{$\mathrm{pH}$}

The range $\mathrm{pH}$ of the treatment combination for meatballs with kecombrang powder was 7.0 to 7.3 (Figure 2). Beef meatballs with the bestcombined treatment were A1B3 (addition of $2 \%$ kecombrang flower powder) with a $\mathrm{pH}$ of $7.10 \pm 0.21$. The $\mathrm{pH}$ of beef meatballs tends to 


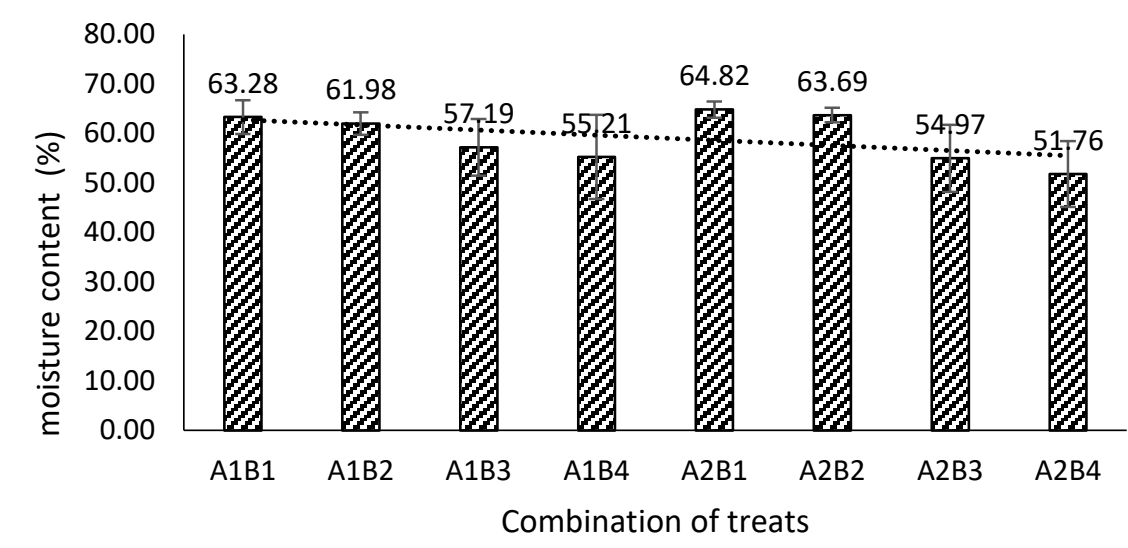

Figure 1. The effect of the combined treatments of the pulverized parts of kecombrang plants $(A)$ with the level of kecombrang preservative powder (B) on the moisture content of beef meatballs. $A 1$, kecombrang flower preservative powder; $A 2$, kecombrang stem preservative powder; $B 1,0 \%$; 2 , $1 \%$; B3, 2\%; B4, 3\%.

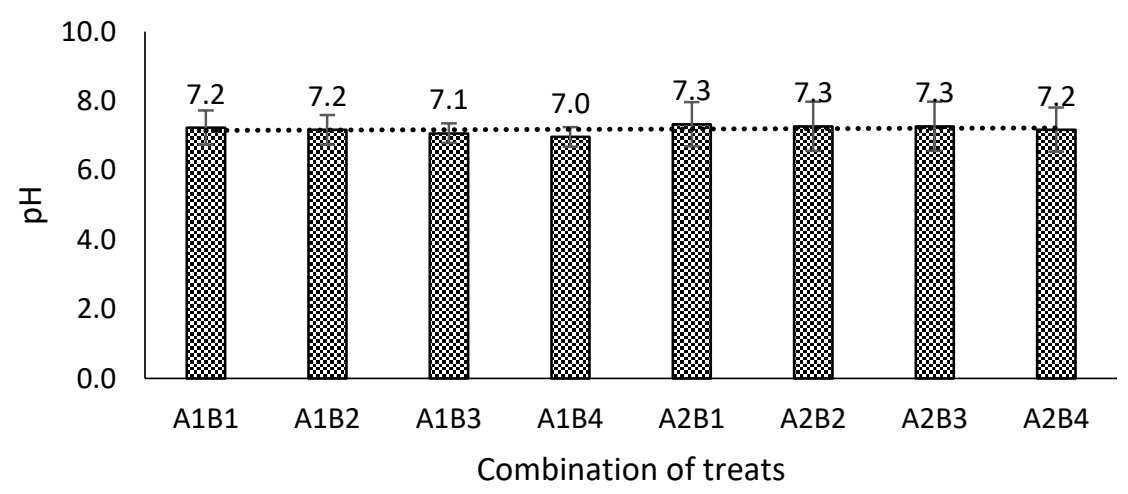

Figure 2. The effect of the combined treatments of the pulverized parts of kecombrang plants $(A)$ with the level of kecombrang preservative powder $(B)$ on the $\mathrm{pH}$ of beef meatballs. $A 1$, kecombrang flower preservative powder; $A 2$, kecombrang stem preservative powder; $B 1,0 \%$; $2,1 \%$; $B 3,2 \%$; $B 4,3 \%$.

decrease with the increased level of kecombrang preservative powder It was presumably because the previous studies reported that the $\mathrm{pH}$ of $1-3 \%$ solvent from kecombrang stem powder was comparatively low, i.e., 3.0-3.2. The low $\mathrm{pH}$ could be attributed to the organic acids in kecombrang flower and stem powder (Naufalin et al., 2019). Organic acids could serve as antimicrobial agents or synergize with the flavonoid compounds because organic acids may damage the microbial cell wall so that the antimicrobial compounds easily enter the cells and render toxicity. As a result, it inhibits the growth of microbes (Naufalin, 2019).

\section{Level of Hydrolyzed Protein (Formol Value)}

Based on data analysis, $2 \%$ of kecombrang powder is sufficient to inhibit protein hydrolysis. The range formol value of the treatment combination for meatballs with kecombrang powder was $1.28 \%$ to $2.09 \%$ (Figure 3). Accordingly, beef meatballs with the best-combined treatment were A1B3 (addition of $2 \%$ kecombrang powder flower) that contained hydrolyzable protein (Formol value) $1.40 \pm 0.35 \%$.

Figure 3 showed that the hydrolyzable protein (Formol value) of beef meatballs decrease with the increased level of kecombrang preservative powder. 


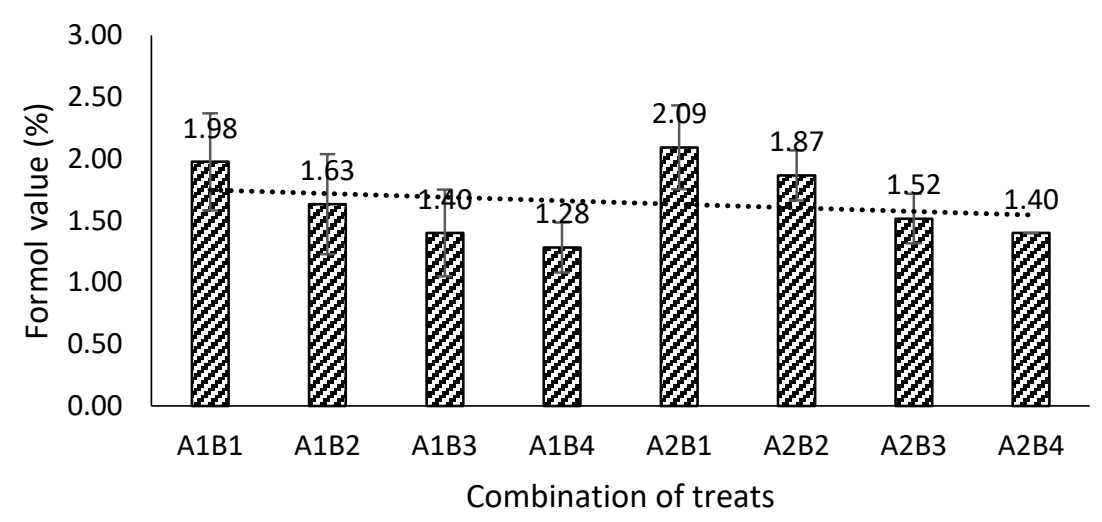

Figure 3. The effect of the combined treatments of the pulverized parts of kecombrang plants $(A)$ with the level of kecombrang preservative powder (B) on the Formol value of beef meatballs. A1, kecombrang flower preservative powder; $A 2$, kecombrang stem preservative powder; $B 1,0 \%$; , $1 \%$; B3, $2 \%$; B4, $3 \%$.

The high concentration may contain more antimicrobial compounds, so it could inhibit the microbes from hydrolyzing the protein, hence lower the Formol value (Naufalin et al., 2019). Jay et al. (2008) reported that bacteria like Clostridium, Bacillus, and Pseudomonas hydr olyze protein into peptides and free amino acids that are subsequently subjected to enzymatic hydrolysis by proteolytic bacteria and produce stench odor.

\section{Sensory evaluation}

The result of sensory evaluation of beef meatballs on color, scents, texture, flavor and preference as presented in Table 2 .

\section{Colour}

The result of the Friedman test showed that the types of powder of kecombrang plant parts, namely flowers and stems, together with the concentration of preservatives did not significantly affect the color of beef meatballs. The color spectrum of beef meatballs ranges from grey to blackish grey. The lowest color score of beef meatballs was $2.72 \pm 1.4$ (whitishgrey) found in $2 \%$ kecombrang flower powder as the selected best treatment. Meanwhile, the highest acceptable factor (100) was $24 \pm 1.30$ (brownish-grey) produced from $3 \%$ kecombrang stem powder (Table 1). However, all combined treatments are not significantly different from the statistical evaluation. The dough of beef meatballs was grey, and kecombrang stem powder is yellowish-white (crème/off white). According to a previous survey (Kumalasari, 2012), color is fourth in the quality ranking based on the consumer preference for meatballs.

\section{Scents}

The result of the Friedman Test showed that the-type of powder of kecombrang plant parts (flowers and stems), together with the concentration of preservatives did not significantly affect the scents of beef meatballs, and then statistical analysis showed that all combined treatments were not significantly different (Table 2). The scents of beef meatballs were between kecombrang and meat. The bestcombined treatments were A1B3 (addition of $2 \%$ kecombrang powder flower) with a value of $3.68 \pm 0.75$ (with meat and kecombrang scents). 
Table 2. The mean result of sensory evaluation of beef meatballs

\begin{tabular}{cccccc}
\hline Sensory Evaluation & Colour & Scents & Texture & Flavor & Preference \\
\hline A1B1 & $2.84 \pm 1.40$ & $3.88 \pm 0.6$ & $3.44 \pm 1.04$ & $3.92 \pm 0.70$ & $3.52 \pm 0.92$ \\
& $(87.65)$ & $(98.98)$ & $(95.56)$ & $(98.99)$ & $(97.78)$ \\
A1B2 & $2.92 \pm 1.19$ & $3.68 \pm 0.85$ & $3.24 \pm 0.67$ & $3.84 \pm 0.85$ & $3.36 \pm 0.95$ \\
& $(90,12)$ & $(93,88)$ & $(90)$ & $(96.97)$ & 93.33 \\
A1B3 & $2.72 \pm 1.40$ & $3.68 \pm 0.75$ & $3.52 \pm 0.65$ & $3.64 \pm 0.49$ & $3.12 \pm 0.97$ \\
& $(83.95)$ & $(93.88)$ & $(97.78)$ & $(91.92)$ & $(86.67)$ \\
A1B4 & $2.88 \pm 1.39$ & $3.80 \pm 0.82$ & $3.24 \pm 0.78$ & $3.64 \pm 0.57$ & $3.24 \pm 0.97$ \\
& $(88.89)$ & $(96.94)$ & $(90)$ & $(91.92)$ & $(90)$ \\
A2B1 & $3.04 \pm 1.27$ & $3.80 \pm 0.76$ & $3.56 \pm 0.58$ & $3.76 \pm 0.66$ & $3.6 \pm 0.92$ \\
& $(93,83)$ & $(96.94)$ & $(98,89)$ & $(94.95)$ & $(100)$ \\
A2B2 & $3.00 \pm 1.15$ & $3.92 \pm 0.86$ & $3.60 \pm 0.76$ & $3.96 \pm 0.61$ & $3.36 \pm 0.86$ \\
& $(95.59)$ & $(100)$ & $(100)$ & $(100)$ & $(93.33)$ \\
A2B3 & $3.12 \pm 1.27$ & $3.56 \pm 0.65$ & $3.20 \pm 0.65$ & $3.64 \pm 0.76$ & $3.20 \pm 0.87$ \\
& $(96.30)$ & $(90.82)$ & $(88.89)$ & $(91.92)$ & $(88.89)$ \\
A2B4 & $3.24 \pm 1.30$ & $3.72 \pm 0.79$ & $3.24 \pm 1.05$ & $3.56 \pm 0.65$ & $2.72 \pm 1.24$ \\
& $(100)$ & $(94.90)$ & $(90)$ & $(89.90)$ & $(75.56)$ \\
\hline
\end{tabular}

Note: A1, kecombrang flower preservative powder; $A 2$, kecombrang stem preservative powder; B1, 0\%; B2, 1\%; B3, 2\%; B4, $3 \%$.

Kecombrang flower has a strong scent (pungent), so the beef scents cannot cover the particular smell of kecombrang. A survey (Kumalasari, 2012) reported that scents is second in the quality ranking of consumer preference who mostly choose for meatballs with the scents of boiled beef.

\section{Texture}

The result of the Friedman test showed that the types of kecombrang plant powder (flowers and stems), together with the concentration of preservatives, did not significantly affect the texture of beef meatballs. The range of beef meatballs texture was from very much chewy to very much not chewy. The best-combined treatment was A1B3 (addition of 2\% kecombrang powder flower) with the value of $3.52 \pm 0.65$ (somewhat chewy) although the acceptable factor (AF) was not the highest because it was not significantly different (statistically) from the other combined treatments (Table 2).

The low texture score of the beef meatballs was presumably due to the less chewiness because of the high level of kecombrang powder. The addition of kecombrang powder could decrease the moisture content of meatball fish, although a higher amount of water would make the product chewier. Kumalasari (2012), reported that texture was the third in the quality ranking of consumer preference where $45.5 \%$ of respondents preferred meatballs with somewhat chewy to a chewy texture.

\section{Flavor}

The result of the Friedman test showed that the types of kecombrang plant powder (flowers and stems), together with the concentration of preservatives did not significantly affect the flavor of beef meatballs. The flavor of beef meatballs in this study ranged from strong kecombrang flavor to strong meat flavor. The best-combined treatment was A1B3 (addition of $2 \%$ kecombrang powder flower) with a value of $3.64 \pm 0.49$ (somewhat chewy) although the AF was not the highest because it was not significantly different (statistically) from the other combined treatments (Table 2).

The low flavor score of beef meatballs added with 3\% kecombrang powder may be attributed to the diminished signature flavor of beef meatballs due to the high level of kecombrang powder. Additionally, the kecombrang stem powder could significantly reduce the meatball saltiness because all treatments received the same amount of salt. Kumalasari (2012), 
reported that flavor was the first in the quality ranking of consumer preference to meatballs, where $91 \%$ of consumers preferred meatballs that were somewhat salty or salty enough.

\section{Preference}

The result of the Friedman test showed that the level of kecombrang stem powder preservatives $(K)$ significantly affected the preference. The preference value of beef meatballs ranged from dislike to like very much. The selected best-combined treatment was A1B3 (addition of $2 \%$ kecombrang powder flower) with the value of $3.12 \pm 0.97$ (somewhat chewy) although the AF was not the highest because it was not significantly different (statistically) from the other combined treatments (Table 2).

The preference value was highly influenced by the panelists' subjectivity and affecting product acceptability. This study found that the higher the level of kecombrang powder mixed with the beef meatballs, the lower the panelists' level of acceptability. The decreased preference level was assumed due to the panelists' evaluation of the colour, scents, texture, and flavor of beef meatballs in this study.

\section{Total Flavonoids}

This study reported the total flavonoids of beef meatballs was $2.42 \mathrm{mg}$ QE/ $100 \mathrm{mg}$. Flavonoids are bioactive compounds that serve as antioxidants. Akhlaghi and Bandy (2009) explained that flavonoids as a metal-chelating agent could chelate metals like $\mathrm{Cu}$ and $\mathrm{Fe}$ that play a role as the catalysts in the Fenton reaction. This reaction is one of the decompositions of hydrogen peroxide into ${ }^{*} \mathrm{OH}$. The metal chelate would decrease the catalytic activity of $\mathrm{Cu}$ and $\mathrm{Fe}$, thus inhibiting the formation of ${ }^{*} \mathrm{OH}$ radicals and automatically decreasing the process of DNA damage and fatty oxidation (PUFA).

The antioxidant activities from plant natural compounds like flavonoids are attributed to the hydroxyl clusters in the molecule structure. Flavonoid antioxidant activities, which is a phenolic compound, are dependent on the molecule structure, particularly the (CH3) $2 \mathrm{C}=\mathrm{CH}-\mathrm{CH} 2-$ prenyl cluster. Flavonoids prenyl clusters are developed for the prevention or therapy of free radicalsassociated diseases. Additionally, flavonoids are phenolic compounds with a conjugated system, which becomes fragile at a high temperature (Pokorny et al., 2001). Sani et al., (2014) stated that some types of flavonoids have a glycoside bound with sugar molecules; therefore, the flavonoid units bind with sugar. Glycoside flavonoids are formed because the hydroxyl clusters in the flavonoids molecule (aglycone) binds with the carbonyl clusters from the sugar (glycone). The glycoside binding was broken at high temperatures. Antioxidant activity in beef meatballs may promote a longer shelf life and can serve as a functional food product.

\section{Total Phenolic}

Total phenolic compounds of beef meatballs in the present study were $179.53 \mathrm{mg} \mathrm{QE} / 100$ $\mathrm{mg}$. The phenolic compounds in kecombrang flower extract can inhibit the formation of free fatty acids due to the oxidation by donating the hydrogen atoms that will bind with the peroxide clusters to produce more stable compounds (Pertiwi et al., 2019). Similarly, Naufalin (2019) stated that the antioxidant properties are derived from the phenolic clusters or their configuration with the molecular structure. Furthermore, phenolic compounds are the potential donors of hydrogen atoms in the initial phase of unsaturated fatty acid oxidation. 
Rezaeizadeh et al., (2011) reported that the hydroxyl clusters in phenolic directly contribute to the antioxidant activities and play a significant role in capturing the free radicals because the hydroxyl clusters of phenolic compounds could donate hydrogen atoms, hence stabilizing the free radical compounds. However, phenolic was broken in particular conditions of heat (temperature), oxygen, light, and the internal factors of kecombrang powder. Some phenolic compounds are easily oxidizable by the oxygen, particularly in an alkali condition or by the polyphenol oxidase enzymes. The total phenolic content of beef meatballs is appropriate for a functional food product.

\section{Conclusion}

Increasing the level of kecombrang flower and stem powder for beef meatballs could decrease the moisture content, $\mathrm{pH}$ and total hydrolysable protein (Formol value) as well as increasing the flavonoids and phenolic, hence improving the shelf life. The addition of kecombrang flower and stem powder did not affect the panellist's evaluation on the color, scents, texture, flavor and preference. The proper addition of kecombrang flower or stem powder into beef meatballs from the physiochemical and sensory quality was $2 \%$.

\section{Acknowledgement}

Sincere gratitude is expressed to the Directorate of Research and Community Service Ristek/BRIN 2020 through the Applied Research.

\section{References}

Akhlaghi, M. and B. Bandy. 2009. Mechanisms of Flavonoids Protection Against Myocardial Ischemia-Reperfusion Injury. Journal of Molecular and Cellular Cardiology, 46(3): 309317.

Alishahi, A. and M. Aïder. 2012. Applications of Chitosan in the Seafood Industry and Aquaculture: A Review. Food and Bioprocess Technology, 5(3): 817-830. https://doi.org/10.1007/s11947-011-0664-x
AOAC. 1995. Official Methods of Analysis of AOAC International. AOAC Washington.

Dutcosky, S. D. 1996. Sensory Analysis of Foods. Ed. Da Champagnat, Curitiba, Brasil.

Kumalasari, H. 2012. Validasi Metoda Pengukuran Moisture Content Bubuk Perisa Menggunakan Moisture Analyzer Halogen HB43-S, sebagai Alternatif Metoda Oven dan Karl Fischer. Bogor (ID): Institut Pertanian Bogor.

Latifasari, N., R. Naufalin and R. Wicaksono. 2019. Edible Coating Application of Kecombrang Leaves to Reduce Gourami Sausage Damage. IOP Conference Series: Earth and Environmental Science, 250 (1). https://doi.org/10.1088/17551315/250/1/012055

Montolalu, S., N. Lontaan, S. Sakul and A. D. Mirah. 2017. Sifat Fisiko-Kimia dan Mutu Organoleptik Meatballs Broiler dengan Menggunakan Tepung Ubi Jalar (Ipomoea batatas L). ZOOTEC, 32(5).

Naufalin, R. 2019. Natural Preservation Opportunities and Challenges in Improving Food Safety. AIP Conference Proceedings, 2094(April). https://doi.org/10.1063/1.5097501

Naufalin, R. and H.S. Rukmini. 2012. Kecombrang Powder ( Nicolaia speciosa) Sebagai Natural Preservatives Pada Meatballs Ikan Tenggiri. Jurnal AGRICOLA II ( 2): 124-147.

Naufalin, R. and H.S. Rukmini. 2018. Antibacterial Activity of Kecombrang Flower Extract (Nicolaia speciosa) Microencapsulation with Food Additive Materials Formulation. IOP Conference Series: Earth and Environmental Science, 102(1). https://doi.org/10.1088/17551315/102/1/012035

Naufalin, R., R. Wicaksono, Erminawati, P. Arsil and K.I.K. Gulo. 2019. Application of Concentrates Flower Kecombrang on Edible Coating as Antioxidant to Suppress Damage on Gourami Sausage. IOP Conference Series: Earth and Environmental Science, 255(1). https://doi.org/10.1088/17551315/255/1/012040

Naufalin, R., R. Wicaksono, Erminawati, P. Arsil and V.Z. Khusna. 2019. Physicochemical Analysis of Gouramy Fish Sausage with Kecombrang Edible Coating Addition. IOP Conference Series: Earth and Environmental Science, 255(1). https://doi.org/10.1088/17551315/255/1/012039

Naufalin, R., R. Wicaksono and E. Triyulianingrum. 2019. Edible Coating Application with Addition of Kecombrang Flower Concentrates to Maintain Quality Fillets of Gurami Fish During Storage. AIP Conference Proceedings, 2094. https://doi.org/10.1063/1.5097500

Pertiwi, D. I., R. Naufalin, P. Arsil, Erminawati, R. Wicaksono and T. Auliya. 2019. Quality of 
Simplician Bioactive Components and Liquid Extract of Kecombrang Flower Powder from Temperature and Time Optimization Results. IOP Conference Series: Earth and Environmental Science, 406(1). https://doi.org/10.1088/17551315/406/1/012008

Pokorny, J., N. Yanishlieva and M.H. Gordon. 2001. Antioxidants in Food: Practical Applications. CRC press.

Jay, J. M., M. J. Loessner and D. A. Golden. 2008. Modern Food Microbiology (Seventh Edition). Springer Science \& Business Media.

Rajkumar, P., R. Kailappan, R. Viswanathan, G. S. V. Raghavan and C. Ratti. 2007. Foam Mat Drying of Alphonso Mango Pulp. Drying Technology, 25(2): 357-365.

Rezaeizadeh, A., A. B. Z. Zuki, M. Abdollahi, Y. M. Goh, M. M. Noordin, M. Hamid and T. I. Azmi. 2011. Determination of antioxidant Activity in Methanolic and chloroformic Extracts of Momordica charantia. African Journal of Biotechnology, 10(24): 4932-4940.
https://doi.org/10.5897/AJB10.1972

Sani, R. N., F. C. Nisa, R. D. Andriani and J. M. Maligan. 2014. Analisis Rendemen dan Skrining Fitokimia Ekstrak Etanol Mikroalga Laut Tetraselmis chuii. Jurnal Pangan Dan Agroindustri, 2(2): 121-126.

Singleton, V. L. and J. A. Rossi. 1965. Colorimetry of Total Phenolics with PhosphomolybdicPhosphotungstic Acid Reagents. American Journal of Enology and Viticulture, 16(3): 144158.

SNI. 1995. Meatballs Daging. Dewan Standardisasi Nasional. Jakarta.

Sudarmadji, S. B. 1997. Haryono dan Suhardi. 1997. Analisa Foodstuffs dan Pertanian. Liberty. Yogyakarta.

Widyaningsih, T. D. and E. S. Murtini. 2006. Alternatif Pengganti Formalin pada Produk Pangan. Trubus Agrisarana. Surabaya.

Yılmaz, I. 2004. Effects of Rye Bran Addition on Fatty Acid Composition and Quality Characteristics of Low-Fat Meatballs. Meat Science, 67(2): 245-249. 